Molekul, Vol. 9. No. 2. November, 2014: 166 - 174

\title{
PENURUNAN KONSENTRASI ZAT WARNA DALAM LIMBAH BATIK MENGGUNAKAN MEMBRAN DARI Sargassum $\mathbf{s p .}$
}

\section{DECREASING OF DYE IN BATIK WASTE USING Sargassum sp. MEMBRANES}

\author{
Senny Widyaningsih*, Dian Windy Dwiasi, Dwi Hidayati \\ Prodi Kimia MIPA, Universitas Jenderal Soedirman \\ *e-mail : sennysetiadi@yahoo.com
}

\begin{abstract}
ABSTRAK
Pencemaran perairan merupakan masalah yang selalu dihadapi oleh industri batik, terutama akibat pemakaian pewarna tekstil. Teknologi membran merupakan salah satu metode yang dapat digunakan untuk pengolahan limbah cair. Membran merupakan lapisan tipis yang berfungsi sebagai filtrasi. Salah satu bahan baku pembuat membran adalah selulosa bakteri. Selulosa bakteri adalah selulosa hasil fermentasi bakteri Acetobacter xylinum yang mengubah glukosa menjadi selulosa.. Penelitian ini memanfaatkan rumput laut jenis alga cokelat (Sargassum sp.) yang dianggap sebagai sampah di pantai sebagai sumber glukosa. Fermentasi alga cokelat dilakukan dengan 3 variasi waktu fermentasi yaitu 7, 10, dan 13 hari. Selulosa bakteri optimum yang dihasilkan adalah selulosa bakteri dengan waktu fermentasi 10 hari, berwarna putih dengan ketebalan $1 \mathrm{~cm}$. Membran Sargassum sp. dihasilkan dengan cara pengepresan selulosa bakteri. Hasilnya membrane Sargassum sp. memiliki ketebalan sebesar 1,8 mm, fluks sebesar 3,386 L. $\mathrm{m}^{-2} \cdot \mathrm{jam}^{-1}$ dan rejeksi sebesar 39,34\%. Membran Sargassum sp. digunakan untuk menurunkan konsentrasi zat warna batik dengan cara filtrasi. Zat warna tersebut adalah rodamin B, metilen biru, dan metal jingga. Penurunan konsentrasi yang diperoleh untuk masing-masing zat warna rodamin $\mathrm{B}$, metilen biru dan metil jingga berturut-turut adalah 80,$04 ; 77,83$ dan $75,84 \%$. Penelitian ini menunjukkan bahwa membran Sargasuum sp. dapat digunakan dalam pengolahan limbah cair industri batik.
\end{abstract}

Kata kunci : Acetobacter xylinu, membran, Sargassum sp., selulosa bakteri, zat warna

\begin{abstract}
Water pollution is a persistent problem faced by the batik industry, mainly due to the use of dyes. Membrane technology is one method that can be used for wastewater treatment. The membrane is a thin layer that serves as a filtration. One of the membrane raw materials is a bacterial cellulose. Bacterial cellulose is a cellulose which is produced from Acetobacter xylinum fermentation that converts glucose into cellulose. This study utilized brown algae (Sargassum sp.) which is regarded as trash on the beach, as a source of glucose. Brown algae fermentation carried out for 7, 10, and 13 days. The optimum resulting bacterial cellulose is the bacterial cellulose with 10 days fermentation, the color is white, and the thickness is $1 \mathrm{~cm}$. Sargasuum sp. membrane are produced by pressing the bacterial cellulose. The Sargassum sp. membrane thickness is $1.8 \mathrm{~mm}$, the flux is $3.386 \mathrm{~L} \mathrm{~m}^{-2} \cdot \mathrm{h}^{-1}$ and the rejection is $39.34 \%$. Sargassum sp. membrane is used to reduce dye concentration of batik by filtration. The dyes are rhodamine $\mathrm{B}$, methylene blue, and methyl orange. Decreasing concentration for rhodamine B, methylene blue, and methyl orange respectively are $80.04 ; 77.83$ and $75.84 \%$. This study shows that the Sargasuum sp. membrane can be used in wastewater treatment of batik industry.
\end{abstract}

Keyword: Acetobacter xylinu, bacterial cellulose, dye, membrane, Sargassum sp. 


\section{PENDAHULUAN}

Industri batik merupakan industri yang sedang berkembang pesat di Indonesia. Industri batik juga berkontribusi pada perkembangan ekonomi karena mampu menyediakan lapangan kerja di daerah masing-masing. Namun, industri batik juga menyumbang pencemaran lingkungan di sekitarnya dengan limbah cairnya. Seiring dengan perkembangan ekonomi, industri batik mengeluarkan semakin banyak limbah yang akan mencemari kualitas air. Pencemaran yang ditimbulkan oleh industri batik adalah limbah zat warna. Seperti diketahui bahwa pewarnaan batik banyak menggunakan zat warna sintetik karena harganya yang relatif murah jika dibandingkan dengan pewarna alami. Penggunaan zat warna sintetik pada industri batik ini menghasilkan limbah zat warna yang menurunkan kualitas air. Limbah zat warna sintetik yang dibuang di perairan bersifat non-biodegradable, tidak dapat diuraikan oleh mikroorganisme.

Zat warna dalam limbah batik yang dibuang tanpa pengolahan terlebih dahulu ke perairan, secara tidak langsung dapat membahayakan kesehatan (Grezechulska dan Morawski, 2002). Selain itu zat warna dalam batas konsentrasi tertentu juga dapat membuat perairan berubah warna karena sulit diuraikan secara alami oleh badan air penerima. Zat warna yang sering digunakan untuk mewarnai batik diantaranya rodamin $\mathrm{B}$, metilen biru, dan metil jingga.

\footnotetext{
Berbagai metode pengolahan limbah telah banyak dilakukan. Beberapa diantaranya adalah koagulasiflokulasi, adsorpsi, dan filtrasi. Salah satu teknik filtrasi yang bisa digunakan adalah teknik filtrasi menggunakan membran. Membran adalah lapisan tipis semipermeabel yang banyak digunakan pada proses pemisahan dan pemekatan
}

(Younos and Tulou, 2005). Membran memisahkan material berdasarkan ukuran dan bentuk molekul, menahan komponen yang mempunyai ukuran lebih besar, dan melewatkan komponen yang lebih kecil. Teknologi membran memiliki kelebihan dibandingkan dengan teknik filtrasi konvensional. Kelebihan tersebut adalah karena penggunaan membran tidak mengubah struktur maupun susunan zat yang dipisahkan, dapat dioperasikan pada suhu ruang sehingga konsumsi energi relatif rendah, tidak beracun karena tidak ada tambahan zat kimia lain, dan merupakan clean technology karena tidak menimbulkan limbah baru (Mulder, 1996).

Umumnya membran dibuat dari bahan polimer. Salah satu polimer untuk pembuatan membran adalah selulosa. Sumber selulosa yang banyak digunakan adalah kayu dan kapas. Kayu dan kapas adalah bahan yang digunakan untuk beberapa industri seperti kertas, tekstil, atau bangunan. Saat ini telah dilakukan penelitian pembuatan membran menggunakan selulosa bakteri (Iskandar dkk, 2010). Selulosa bakteri adalah selulosa yang diproduksi oleh bakteri Acetobacter xylinum melalui teknik fermentasi. Bakteri ini akan mengubah glukosa menjadi selulosa pada media asam. Lamanya waktu fermentasi mempengaruhi ketebalan selulosa bakteri yang dihasilkan. Semakin lama waktu fermentasi, selulosa bakteri yang dihasilkan semakin tebal. Pada umumnya lama fermentasi selulosa bakteri adalah 7-14 hari. Selulosa bakteri dipilih sebagai sumber selulosa karena selulosa ini mudah dibuat menggunakan bahan alami yang memiliki kandungan glukosa. Selain itu selulosa bakteri memiliki keunggulan karena kemurniannya tinggi, derajat kristalinitasnya tinggi, kekuatan tarik tinggi, elastis, dan biodegradable (Krystinowicz, 2001). Bila dibandingkan 
sumber selulosa lain, maka selulosa bakteri tidak akan menghabiskan sumber daya alami dan tidak bersaing dengan industri lain yang menggunakan kayu dan kapas sebagai bahan dasarnya.

Umumnya bahan yang mengandung glukosa dapat dibuat menjadi selulosa bakteri. Alga cokelat adalah salah satunya. Alga cokelat jenis Sargassum sp. memiliki kandungan glukosa sebesar 19,06\% (Yunizal, 2004) sehingga dapat menjadi bahan dasar pembuatan selulosa bakteri. Disamping itu alga coklat sering dianggap sebagai sampah karena mengotori pantai. Oleh karena itu pemanfaatan alga coklat sebagai sumber selulosa bakteri dapat menambah nilai ekonominya. Terlebih lagi bila dimanfaatkan lebih lanjut menjadi membran.

Penelitian ini bertujuan mengetahui kinerja membran dari Sargassum sp. dalam memisahkan zat warna batik. Variasi waktu fermentasi selulosa bakteri dilakukan untuk mendapatkan selulosa bakteri terbaik. Karakteristik selulosa bakteri dan membran Sargassum sp dilakukan untuk mendapatkan hasil optimum. Hasil pengolahan limbah dilihat berdasarkan persen penurunan konsentrasi zat warna seperti rhodamin $\mathrm{B}$, metilen biru, dan metil jingga.

\section{METODE PENELITIAN}

\section{Alat dan Bahan}

Peralatan yang digunakan dalam penelitian ini adalah peralatan gelas, kain blacu/mori, kertas saring, nampan, sel filtrasi, $\mathrm{pH}$ indikator, spektrofotometer UV-Vis Shimadzu 1800, hand-press, tensile test Zwick ZO. Bahan-bahan yang digunakan dalam penelitian ini adalah limbah cair industri batik, bibit starter Acetobacter xylinum, Sargassum $s p$, gula pasir, $\left(\mathrm{NH}_{4}\right)_{2} \mathrm{SO}_{4}, \mathrm{NaOH} 2 \%$ (b/v), asam asetat $1 \%(\mathrm{v} / \mathrm{v})$, akuades, dekstran T-500, fenol 5\% (b/v), $\mathrm{H}_{2} \mathrm{SO}_{4}$ pekat, asam asetat glasial, rodamin $\mathrm{B}$, metilen biru, dan metil jingga.

\section{Prosedur Penelitian}

Selulosa bakteri (Anastasia, dan Afrianto, 2008)

Sebanyak 25 gram rumput laut Sargassum sp. dicuci dan ditiriskan. Selanjutnya rumput laut dihancurkan dengan menggunakan blender dan disaring untuk mendapatkan filtratnya. Filtrat tersebut ditambahkan air dengan perbandingan 1 : 20 atau sampai volumenya mencapai $500 \mathrm{~mL}$ lalu dimasak selama \pm 15 menit pada suhu 80 ${ }^{\circ} \mathrm{C}$. Lima belas menit setelah dimasak, masukan gula (50 gram) dan ammonium sulfat (5 gram) kemudian tambahkan asam asetat glasial sampai $\mathrm{pH}=4$. Setelah proses pemasakan selesai maka rumput laut siap untuk ditempatkan dalam wadah fermentasi yang telah dicuci bersih dan disterilkan. Wadah ditutup dengan menggunakan kertas steril dan didiamkan selama satu malam kemudian ditambahkan A. xylinum (50 $\mathrm{mL}$ ), ditutup menggunakan kertas koran dan difermentasikan selama 7 (T1), 10 (T2), dan 13 (T3) hari pada suhu $25{ }^{\circ} \mathrm{C}$ sehingga diperoleh selulosa bakteri.

\section{Membran Sargassum sp.}

Selulosa bakteri hasil fermentasi yang berupa gel dicuci dengan air mengalir selama 24 jam setelah itu direndam oleh $\mathrm{NaOH} \quad 2 \%$ sambil dipanaskan selama 1 jam pada suhu 80$90{ }^{\circ} \mathrm{C}$. Kemudian gel direndam dengan asam asetat $1 \%$. Terakhir nata dicuci kembali dengan air mengalir selama 24 jam. Gel yang telah dimurnikan selanjutnya ditekan dengan alat handpress hingga diperoleh lembaran tipis membran. Film yang diperoleh selanjutnya dikeringkan pada suhu $\operatorname{kamar}\left( \pm 27-30{ }^{\circ} \mathrm{C}\right)$. 


\section{Penentuan massa jenis}

Pengujian massa jenis dilakukan dengan cara membandingkan massa membran Sargassum sp. dengan volumenya. Membran Sargassum sp. ditimbang dan diperoleh berat kering membran Sargassum sp. Volume membran Sargassum sp. dihitung, kemudian dibandingkan dan diperoleh nilai massa jenisnya.

\section{Penentuan fluks}

Nilai fluks ditentukan dengan meletakkan kertas saring dan membran Sargassum sp. pada sel filtrasi. Air sebanyak $\pm 150 \mathrm{~mL}$ dimasukkan ke dalam sel filtrasi kemudian ditutup rapat dan diberikan tekanan udara sebesar 3 $\mathrm{kgf} / \mathrm{cm}^{2}$. Setelah itu permeat atau larutan yang melewati membran yang keluar ditampung selama selang waktu tertentu dengan interval 10 menit dan diukur volumenya. Pengukuran ini dilakukan sampai didapat volume yang konstan.

\section{Penentuan Rejeksi}

Rejeksi membran ditentukan dengan menggunakan larutan Dekstran T-500 dengan konsentrasi 1000 ppm. Larutan permeat dan konsentrat masingmasing diambil $1 \mathrm{~mL}$ lalu dimasukkan ke dalam labu ukur $10 \mathrm{~mL}$ dan diencerkan sampai tanda batas. Masingmasing larutan direaksikan dengan fenol 5\% dan asam sulfat pekat dengan perbandingan $1: 1: 5$. Larutan dikocok dan dibiarkan sampai dingin kemudian diukur absorbansinya dengan spektrofotometer visible pada panjang gelombang $490 \mathrm{~nm}$. Penentuan konsentrasi permeat dihitung berdasarkan kurva standar. Kurva standar dibuat menggunakan larutan dekstran T-500 dengan konsentrasi 10, 40, 70, 100, 130, 160, 190, 220 dan 250 ppm. Larutan-larutan tersebut diperlakukan sama seperti di atas, yaitu ditambahkan fenol 5\% dan asam sulfat pekat dengan perbandingan $1: 1: 5 \mathrm{ke}$ dalam labu ukur $10 \mathrm{~mL}$ dan diencerkan sampai tanda batas kemudian diukur dengan spektrofotometer visible panjang gelombang $490 \mathrm{~nm}$.

\section{Penentuan kekuatan tarik}

Membran dipotong menyerupai bentuk dumb-bell dan diukur panjang awalnya (lo). Bagian kedua ujung dijepit pada alat uji tarik lalu ditarik sampai membran putus. Monitor akan menunjukkan besarnya gaya tarik yang dibutuhkan untuk memutuskan membran dan nilai perpanjangan/ elongation $(\Delta \mathrm{l})$.

\section{Pembuatan larutan standar rodamin $B$, metil biru dan metil jingga}

Sebanyak 1 gram masing-masing serbuk zat warna dilarutkan dalam 20 $\mathrm{mL}$ akuades, kemudian dipindahkan ke dalam labu ukur $1000 \mathrm{~mL}$ dan ditambahkan akuades sampai tanda batas. Larutan ini merupakan larutan induk zat warna 1, 2, 3, 4, 5, 6, 7, 8, 9, dan $10 \mathrm{mg} / \mathrm{L}$ sebanyak $100 \mathrm{~mL}$ melalui pengenceran larutan induk $1000 \mathrm{mg} / \mathrm{L}$ sesuai dengan hukum pengenceran. Salah satu larutan tersebut digunakan untuk menentukan panjang gelombang maksimum. Larutan zat warna $5 \mathrm{mg} / \mathrm{L}$ diukur panjang gelombang 410-700 nm dengan interval $10 \mathrm{~nm}$. Panjang gelombang pada serapan maksimum digunakan untuk pengukuran dalam penelitian ini. Selanjutnya untuk kurva standar dilakukan dengan masingmasing larutan zat warna konsentrasi 1 , 2, 3, 4, 5, 6, 7, 8, 9, dan $10 \mathrm{mg} / \mathrm{L}$ diukur dengan spektrofotometer visible. Kurva kalibrasi standar dibuat dengan memplotkan kurva hubungan antara konsentrasi (X) dengan absorbansi (Y) untuk masing-masing zat warna.

\section{Filtrasi membran}

Membran yang diperoleh kemudian dipotong sesuai dengan desain alat filtrasi. Kertas saring dimasukkan ke dalam sel dan membran Sargassum sp.. Sampel limbah cair sebanyak $150 \mathrm{~mL}$ 
dimasukkan dalam sel filtrasi kemudian ditutup rapat, dan diberikan tekanan udara sebesar $3 \mathrm{kgf} / \mathrm{cm}^{2}$. Permeat yang keluar dari sel filtrasi ditampung.

\section{Penentuan persentase penurunan zat warna limbah batik}

Sampel limbah cair batik ditentukan konsentrasi awal dan akhir dengan mengukur absorbansi pada panjang gelombang maksimum pada masing-masing zat warna. Setelah itu, di hitung konsentrasinya dengan menggunakan persamaan garis yang telah didapatkan pada kurva standar masing-masing zat warna. Kemudian dapat dihitung persentase penurunan kadar rhodamin B, metil biru dan metil jingga dalam limbah cair industri batik dengan rumus sebagai berikut:

$$
\text { Penurunan Kadar (\%) }=\frac{\text { Konsentrasi awal }- \text { kunsentrasi alkhir }}{\text { Konstuntasi awal }} \times 100 \%
$$

\section{HASIL DAN PEMBAHASAN}

\section{Selulosa bakteri}

Selulosa bakteri yang dihasilkan dengan berbagai waktu fermentasi berwarna putih dan memiliki tekstur yang kenyal.

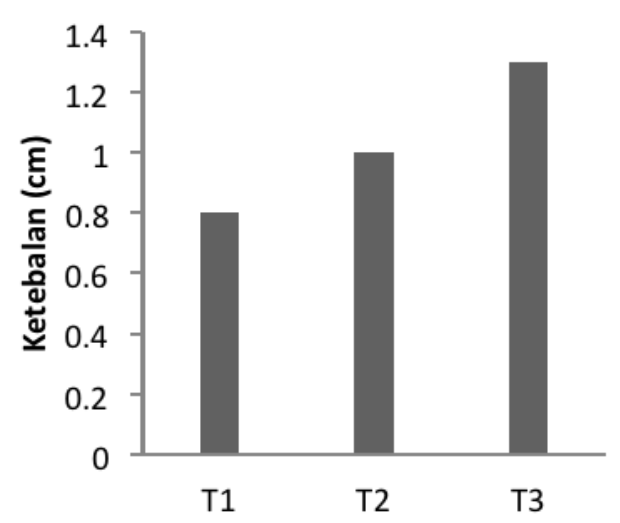

Gambar 1. Ketebalan selulosa bakteri Sargassum $s p$ terhadap waktu fermentasi (T1:7 hari, $\mathrm{T} 2: 10$ hari, $\mathrm{T} 3: 13$ hari)

Gambar 1 menunjukkan semakin lama waktu fermentasi, selulosa bakteri yang dihasilkan semakin tebal (Heryawan, 2004). Hal ini dikarenakan semakin lama waktu fermentasi, maka semakin banyak selulosa yang dipintal oleh bakteri Acetobacter xylinum (Nurfiningsih, 2009). Pada proses fermentasi terjadi reaksi polimerisasi glukosa menjadi selulosa, glukosa yang berperan dalam pembentukan selulosa adalah glukosa yang ada dalam bentuk $\alpha$ akan diubah dalam bentuk $\beta$ dengan bantuan enzim isomerase yang berada pada bakteri Acetobacter xylinum (Piluharto, 2003).

\section{Membran Sargassum sp.}

Membran diperoleh dengan cara pengepresan selulosa bakteri menjadi lapisan tipis. Pengpresan dilakukan dengan kondisi yang sama untuk semua variasi selulosa bakteri. Selulosa bakteri yang lebih tebal akan menghasilkan membran yang juga lebih tebal. Gambar 2. menunjukkan bahwa semakin tebal selulosa bakteri maka membran yang diperoleh juga semakin tebal.

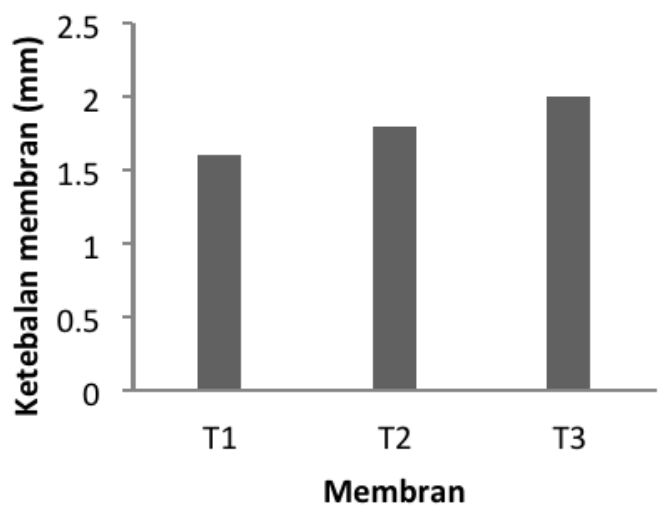

Gambar 2. Ketebalan membran Sargassum sp. Terhadap waktu fermentasi (T1:7 hari, $\mathrm{T} 2: 10$ hari, T3:13 hari) 


\section{Massa jenis membran Sargassum sp.}

Massa jenis dihitung dengan membagi atau membandingkan berat membran dalam satuan gram dengan volume membran dalam satuan $\mathrm{cm}^{3}$. Tinggi membran dapat diasumsikan sebagai tebal membran karena membran merupakan lapisan tipis yang hanya mempunyai ketinggian dalam ukuran milimeter $(\mathrm{mm})$ ataupun mikrometer $(\mu \mathrm{m})$. Gambar 3. menunjukkan semakin tebal membran maka massa jenisnya semakin besar.

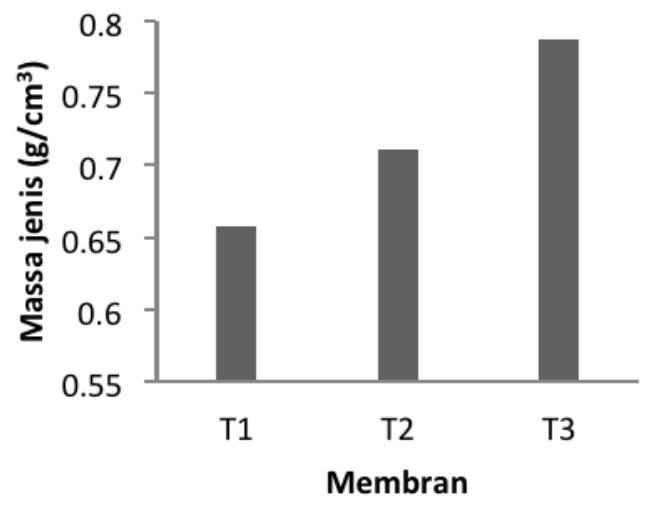

Gambar 3. Massa jenis membran Sargassum sp. untuk ketiga variasi membran

\section{Fluks (permeabilitas)}

Fluks (Permeabilitas) merupakan ukuran banyaknya volume permeat per satuan luas membran yang ditentukan dalam jangka waktu tertentu (Mulder, 1996). Besarnya nilai fluks pada membran dari Sargassum sp. dilakukan dengan menghitung menggunakan rumus:

$$
\mathrm{v}=\frac{\mathrm{v}}{\mathrm{h} \cdot \mathrm{t}}
$$

Dimana,

$\mathrm{Jv}=$ fluks volume $\left(\mathrm{L} / \mathrm{m}^{2} . \mathrm{jam}\right)$

$\mathrm{t}=$ waktu (jam)

$\mathrm{A}=$ luas permukaan membran $\left(\mathrm{m}^{2}\right)$

$\mathrm{V}=$ volume permeat $(\mathrm{L})$
Nilai fluks membran berbanding terbalik terhadap fungsi waktu, yaitu dengan semakin bertambahnya waktu maka nilai fluks akan cenderung semakin turun. Nilai fluks akan turun secara terus-menerus hingga tercapai keadaan tunak. Hal ini dapat terjadi akibat adanya polarisasi konsentrasi atau terjadinya fouling pada permukaan membran (Mulder, 1996).

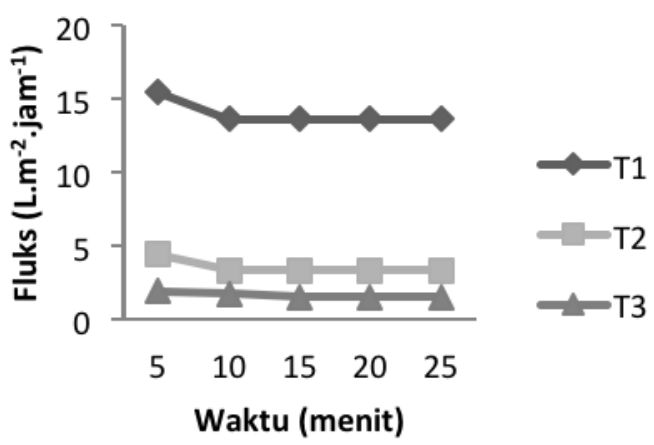

Gambar 4. Fluks membran Sargassum sp. untuk air dan dekstran

Gambar 4. menunjukkan bahwa fluks untuk membran $\mathrm{T} 1$ memiliki nilai yang paling besar. Membran T1 adalah membran yang memiliki ketebalan paling rendah. Semakin tebal suatu membran maka semakin rendah fluks membran tersebut. Besarnya fluks ditentukan oleh banyaknya pori dan ukuran pori (Piluharto, 2003). Membran yang tebal cenderung memiliki pori-pori yang kecil sehingga waktu yang dibutuhkan oleh air untuk melewati membran menjadi lama. Ketebalan membran berbanding terbalik dengan fluksnya. Namun, membran T2 dan T3 memiliki perbedaan nilai yang tidak terlalu besar dibandingkan dengan membran T1.

\section{Rejeksi (selektivitas)}

Rejeksi merupakan kemampuan suatu membran dalam menahan spesi yang melewati membran. Besarnya koefisien rejeksi diperoleh dari nilai konsentrasi permeat dan konsentrasi feed 
yang diukur dengan spektrofotometer visible. Umumnya nilai persentase rejeksi membran berbanding terbalik dengan nilai fluks suatu membran. Semakin kecil nilai fluks, maka semakin besar nilai persentase rejeksi suatu membran. Nilai rejeksi membran dapat dihitung dengan menggunakan rumus sebagai berikut:

$$
\mathrm{R}_{\mathrm{M} 1}(\%)=1-\frac{\mathrm{C}_{\mathrm{M} 1 \text {; purnedt) }}}{\mathrm{C}_{\mathrm{K} / 1 \text { (twed): }}} \times 100
$$

$\mathrm{C}_{\mathrm{M} 1 \text { (permeat) }}$ adalah konsentrasi permeat, yaitu konsentrasi larutan yang telah melewati membran, sedangkan $\mathrm{C}_{\mathrm{M} 1 \text { (feed)s }}$ adalah konsentrasi feed, yaitu konsentrasi larutan sebelum melewati membran. Pengukuran konsentrasi tersebut berdasarkan kurva kalibrasi dengan persamaan $\mathrm{y}=0,0368 \mathrm{x}+0,020$ dan nilai $r=0,988$.

Membran T2 memiliki nilai persentase rejeksi yang lebih tinggi daripada T1. Ukuran pori membran yang semakin kecil maka akan lebih banyak menahan spesi yang melewatinya dan sebaliknya. Membran yang tebal memiliki pori-pori yang kecil sehingga persen rejeksi membran tersebut besar. Semakin besar ketebalan membran maka semakin besar persentase rejeksinya. Namun, untuk membran T3 nilai persentase rejeksinya paling rendah. Hal ini diduga karena membran T3 memiliki struktur yang rapuh sehingga ketika diberi tekanan, pori-pori membran membesar dan tidak mampu lagi menahan spesi yang melewatinya. Membran T3 adalah membran dari selulosa bakteri dengan waktu fermentasi yang paling lama. Kerapuhan membran T3 ini dibuktikan melalui nilai modulus

Young pada penentuan kekuatan tarik.

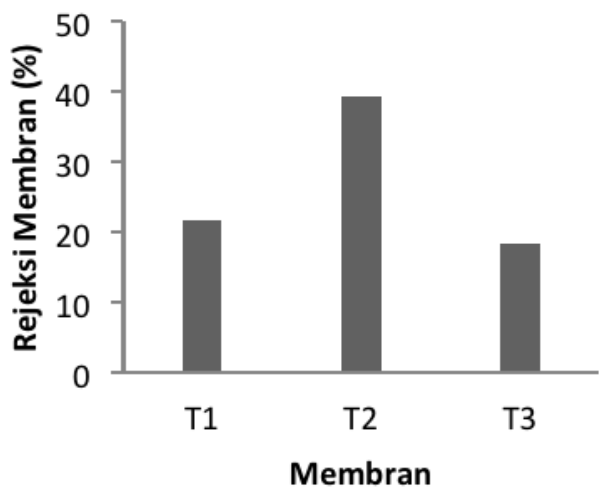

Gambar 5. Rejeksi membran terhadap waktu fermentasi (T1:7 hari, $\mathrm{T} 2: 10$ hari, T3:13 hari)

\section{Kekuatan tarik}

Uji kekuatan tarik dilakukan untuk mengetahui sifat mekanik dari suatu bahan karena pengujian tersebut merupakan dasar dari pengujianpengujian mekanik dan studi mengenai kekuatan suatu material terhadap gaya yang berasal dari luar yang dapat merusak material, dalam hal ini adalah membran. Menurut Iskandar dkk (2010), Uji tarik atau daya regang putus (tensile stenght) adalah gaya tarik maksimum yang dapat dicapai sampai film tetap bertahan sebelum film kemudian putus atau sobek. Sampel yang digunakan biasanya berbentuk dumbbell sehingga akan terjadi pemutusan pada daerah pusat, jauh dari wilayah pegangan. Kuat tarik membran biasanya dilihat dari nilai modulusnya. Modulus adalah ukuran dari ketahanan suatu material untuk mengalami perubahan bentuk.

Tabel 1. Hasil uji kekuatan tarik membran Sargassum sp.

\begin{tabular}{cccc}
\hline Membran & Stress (N) & Strain (\%) & Modulus Young (MPa) \\
\hline T1 & 21.2008 & 10.1106 & 2.0969 \\
T2 & 25.27049 & 12.3329 & 2.0490 \\
T3 & 16.11905 & 21.4846 & 0.7503 \\
\hline
\end{tabular}


Hasil uji kekuatan tarik menunjukkan bahwa membran $\mathrm{T} 1$ dan T2 memiliki nilai modulus Young yang tidak berbeda jauh, namun membran T3 memiliki nilai yang sangat rendah (Tabel 1). Rendahnya kekuatan tarik membran T3 menunjukkan bahwa membran memiliki struktur yang rapuh. Hal ini menyebabkan membran memiliki persentase rejeksi yang rendah pula.

\section{Persentase Penurunan Konsentrasi Zat Warna Limbah Cair Batik}

Berdasarkan karakterisasi membran maka membran yang memiliki kinerja paling tinggi adalah membran T2. Membran T2 ini digunakan untuk mengolah limbah cair batik. Nilai fluks untuk limbah cair batik adalah sebesar 2,7088 L.m ${ }^{-2} \cdot \mathrm{jam}^{-1}$. Konsentrasi limbah cair batik sebelum difiltrasi dengan membran dapat ditentukan dengan mengukur absorbansinya pada panjang gelombang maksimum masing-masing zat warna rodamin $\mathrm{B}$, metilen biru dan metil jingga. Hasil pengukuran panjang gelombang maksimum untuk rodamin $\mathrm{B}$, metilen biru, dan metal jingga berturutturut adalah 553,70; 664,20 dan 464,50 nm. Sedangkan pada penentuan kurva kalibrasi zat warna didapatkan persamaan $y=0.25707 x-0.01325$ untuk rodamin $\mathrm{B}, \mathrm{y}=0.245 \mathrm{x}-0.031$ untuk metilen biru dan $\mathrm{y}=0.068 \mathrm{x}-0.01833$ untuk metil jingga, dengan nilai $r$ untuk rodamin B sebesar 0,999; 0,998 untuk metilen biru dan 0,999 untuk metil jingga. Hasil penelitian menunjukkan persentase penurunan konsentrasi zat warna pada limbah cair batik untuk rodamin $\mathrm{B}$, metilen biru dan metil jingga secara berturut-turut adalah 80,$04 ; 77,83$ dan $75,84 \%$.

\section{KESIMPULAN}

Berdasarkan hasil penelitian yang diperoleh maka dapat diambil kesimpulan sebagai berikut:
1. Membran Sargassum sp optimum adalah membran dengan waktu fermentasi 10 hari dengan ketebalan selulosa bakteri $1 \mathrm{~cm}$ dan ketebalan membran $1,8 \mathrm{~mm}$

2. Membran Sargassum sp optimum memiliki nilai fluks sebesar 3,386 L.m ${ }^{-2} . \mathrm{jam}^{-1}$, rejeksi sebesar $39,34 \%$, dan modulus Young sebesar 2,0490 $\mathrm{MPa}$.

3. Persentase penurunan konsentrasi zat warna rodamin $\mathrm{B}$, metilen biru dan metil jingga secara berturut-turut yaitu sebesar 80,04; 77,83 dan $75,84 \%$.

\section{DAFTAR PUSTAKA}

Anastasia, N dan E. Afrianto, 2008, Mutu Nata de Seaweed Berbagai Konsentrasi Sari Jeruk Nipis, Prosiding Seminar Nasional Sains dan Teknologi- II, Universitas Lampung, Lampung.

Grezechulska and Morawskin, 2002, Photocatalytic Decomposition of Azo-Dye Acid Black 1 in Water Over Modified Titanium Dioxide, App. Catal $B$ : Environmental, 36, 45.

Heryawan, 2004, Pengaruh Konsentrasi Gula dan Lamanya Waktu Fermentasi terhadap Mutu Nata de Pina, Laporan Penelitian, Jurusan Teknologi Hasil Pertanian, Fakultas Pertanian, Universitas Syiah Kuala. Banda Aceh.

Iskandar, M. Zaki, S. Mulyati, U. Fathanah, I. Sari, Juchairawati, 2010, Pembuatan Film Selulosa dari Nata de Pina, Jurnal Rekayasa Kimia dan Lingkungan, Vol. 7, No. 3, Hal 105-111. 
Krystinowicz, 2001. Biosynthesis of Bacterial Cellulose and Its Potential Application in The Different Industrie. http://www.biotechnology.pl.c om/science/krystynomcz.htm

Mulder, M., 1996, Basic Principle of Membrane Technology, Kluwer Academic Publishing, Netherlands.

Nurfiningsih, 2009. Pembuatan Nata de Corn dengan Acetobacter xylinum, Seminar Tugas Akhir, Jurusan Teknik Kimia, Fakultas Teknik, Universitas Diponegoro. Semarang.
Piluharto, B, 2003, Kajian Sifat Fisik Film Tipis Nata de Coco sebagai Membran Ultrafiltrasi, Jurnal Ilmu Dasar, Vol.4, No.5, Hal 52 - 57.

Younos, T. and K.E. Tulou, 2005, Overview of Desalination Techniques, J. Contempore Water Res Educ, Vol.132: 3 10.

Yunizal, 2004, Teknik Pengolahan Alginat, Pusat Riset Pengolahan Produk dan Sosial Ekonomi Kelautan dan Perikanan. Jakarta 